\title{
Ida-Siberi Minussinski piirkonna eestlaste ravitsejad, haigusseletused ja ravivõtted. Traditsioonimuutused ja kogumiskontekst
}

\author{
Anu Korb
}

Teesid: Artiklis on vaatluse all Ida-Siberi Krasnojarski krai Minussinski piirkonna eestlaste rahvameditsiini-alase traditsiooni muutumine viimase 40-50 aasta vältel ja kogukonna materjali talletamine Eesti Rahvaluule Arhiivi. Jälgin ajastuomaseid poliitiliste mõjudega kogumisperioode, muutusi pärimusekandjate ja pärimusgrupi, kogujate ja kogumistöö juhendajate arusaamades, mille tulemusena on Eesti Rahvaluule Arhiivi (ERA) laekunud rahvameditsiini-alane aines.

Nõukogude võimu aastail jäi rahvameditsiini-alase teabe talletamine kogumistöö äärealale. Vältimaks võimuorganite sekkumist, püüdsid kogumistöö juhendajad ja kogujad näidata rahvaravi traditsiooni kogumist kui kaduva minevikulise nähtuse fikseerimist. Alates 1990. aastaist sai rahvameditsiini puutuvat koguda ideoloogiliste piiranguteta. Samas oli rahvapäraste ravimisviiside ja -võtete kasutamine 1960.-1970. aastail ja ka 1990. aastail Minussinski piirkonna eesti kogukondades pärimusrühma ühine teadmine, oskused ja ravisõnad arvati olevat igaühele kättesaadavad ja õpitavad. Paarkümmend aastat hiljem olid ravitsemisoskused koondunud üksikute teadjate kätte, sest vananeva elanikkonnaga külades polnud piisavalt traditsiooni jätkajaid. 
Märksõnad: ideoloogia, kogukond, pärimuse kogumine, rahvameditsiin, ravitseja, Siberi eestlased

\section{Asustusloost ja külade tänapäevast}

Luterlaste koloonia Ülem-Suetuk Ida-Siberis, kus elas ka eestlasi, sai alguse 19. sajandi keskpaiku Vene tsaarivalitsuse poolt väljasaadetutest ja sundasunikest. Kui asunduses jäi kitsaks, moodustati uued külad rahvuste järgi. Ülem-Suetuk sai tuntuks soomlaste külana, eestlaste küla Ülem-Bulanka sai alguse 1861. aastal. 19. sajandi viimasel kümnendil ja 20. sajandi algupoolel lisandus asundustesse oma maa otsingul väljarännanuid (Must 2012, 365-402). Kuna soomlasi alates 20. sajandi algusest juurde ei tulnud, sulandusid keelelt ja kultuurilt sarnased soomlased eestlastega, Ülem-Suetuk muutus ajapikku eestikeelseks külaks.

Külad said hiljem kannatada sõdades (Venemaa kodusõda, Esimene ja Teine maailmasõda) ja repressioonides. Pärast Teist maailmasõda algas massiline küladest lahkumine emamaale Eestisse,

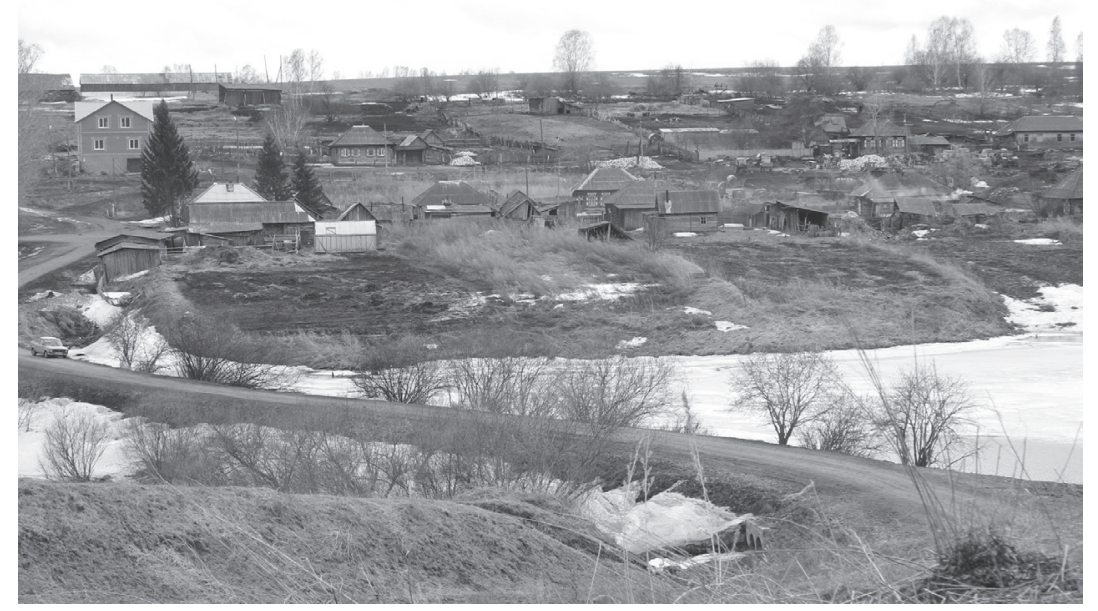

Ülem-Suetuki külavaade. Anu Korbi foto 2013 (ERA, VF 5341). 
ümberkaudsetesse Vene linnadesse ja asulatesse. Kuna vaatlusalused külad asusid keskustest ja suurtest teedest eemal, oli neisse teistest rahvustest juurdetulijaid vähe, elanike arv vähenes kiiresti.

\section{Analüüsiaines}

Varasemast perioodist leidub ajakirjanduses ja ülevaateteostes (nt Nigol 1918) Ida-Siberi elu-olu kirjeldusi, kuid piirkonna eestlaste pärimuse kogumisest saame rääkida alates 20. sajandi 1960.1970. aastaist.

Artikli analüüsimaterjaliks on Minussinski piirkonna Ülem-Suetuki (vn Verhnij Suetuk) ja Ülem-Bulanka (vn Verhnjaja Bulanka) külas sündinud-kasvanud eestlastelt ajavahemikus 1969-2013 talletatud rahvameditsiini-alane aines: käsikirjalised ülestähendused, alates 1990. aastaist ka heli- ja videosalvestused. Kuna külad asuvad lähestikku ja neist talletatud pärimus on sarnane, saab kogutud materjali käsitleda Minussinski piirkonna eestlaste pärimusena. Ravitsejaid, haigusseletusi, ravivõtteid jms käsitlevat materjali koguti osana frontaalsest kogumistööst. Mõistagi ei saa rahvameditsiini puutuvat ainest muust vaimsest pärimusest jäigalt eraldada, sest see sisaldab muu pärimusega ühisalasid ja kokkupuutepunkte (nt usundiline muistend, surmakultuur, sünnikombestik).

Eesti Rahvaluule Arhiivi laekunud Ida-Siberi eestlaste rahvameditsiini-alase materjali kogumisel on võimalik eristada kolm perioodi:

1) Kirjandusmuuseumi rahvaluule osakonna ${ }^{1}$ kaastöölise Rosalie Ottessoni käsikirjalised kirjapanekud nõukogude võimu perioodil, aastatel 1969-1976.

2) Eesti Rahvaluule Arhiivi kogumismatkad 1991. ja 1992. aastal.

${ }^{1}$ Nõukogude korra kehtestamise järel 1940. aastal jaotati Eesti Rahva Muuseum, mille koosseisu kuulus ka Eesti Rahvaluule Arhiiv, kaheks iseseisvaks asutuseks: Riiklikuks Etnograafiliseks Muuseumiks ja Riiklikuks Kirjandusmuuseumiks. Etnograafiline Muuseum esemeliste kogudega jäi Tartu lähedale Raadi mõisa, Riiklik Kirjandusmuuseum sõnavaraliste kogudega endistesse ruumidesse Tartus Aia (nüüd Vanemuise) tänavas. Eesti Rahvaluule Arhiivist sai kirjandusmuuseumi rahvaluule osakond. 1995. aastal taastati Eesti Rahvaluule Arhiivi nimi osakonna nimetusena. 
3) Eesti Rahvaluule Arhiivi kogumismatkad 2012. ja 2013. aastal. ${ }^{2}$

\section{Kollektiivne mälu ja kultuuriidentiteet}

Artiklis lähtun sotsioloog Maurice Halbwachsi ja kunstiajaloolase Aby Warburgi välja töötatud "kollektiivse" ehk "sotsiaalse mälu" teooriast. Kollektiivse mälu teooriat arendasid edasi saksa õpetlased Aleida ja Jan Assmann (Tamm 2013, 125). Selle kohaselt püsib kuulumine teatud ühiskonda ja selle kultuuri sotsialiseerumise ja traditsioonide toel. Seega individuaalne mälu kujuneb suhtluses teistega. Nendeks teisteks ei ole mitte suvaline inimmass, vaid rühmad, kellel on iseendast, s.t oma ühtsusest ja eripärast teatud pilt või kujutlus ning kes toetavad seda teadlikkusega ühisest minevikust (Assmann 2012, 1776-1777). Tavaliselt jagatakse oma vaateid, uskumusi ja teadmisi teistega oma kultuurilise kogukonna raames (Kõresaar 2005, 9). Samas jääb minevikust alles vaid see, mida ühiskond igal ajastul oma kaasaegses taustsüsteemis rekonstrueerida suudab (Halbwachs 1985). Kultuurimälu seostab oma teadmised oleviku tegeliku olukorraga. Kultuurimälu mõiste moodustavad kõik need igale ühiskonnale ja igale ajastule iseloomulikud taaskasutatavad tekstid ja riitused, mida "kultiveerides" ühiskond oma minapilti stabiliseerib ja edasi annab, kollektiivselt jagatud teadmine, millele toetub rühma teadlikkus oma ühtsusest ja eripärast. See teadmine ei ole sisult erinev mitte ainult kultuuriti vaid ka ajastuti. Pärimuse siduvuse ja refleksiivsuse määr võib suuresti varieeruda (Assmann 2012, 1780-1783).

\section{Rahvameditsiini mõiste ja Eesti kogumistraditsioon}

Koolimeditsiini ehk professionaalse teadusliku meditsiini tekkimise algusaegadest peale on püütud koolimeditsiini ja rahvameditsiini vahekordi selgitada. Koolimeditsiini valdkonnas tegutsevail ravijail

${ }^{2}$ Piirkonnas toimusid Eesti Rahvaluule Arhiivi välitööd ka 2000. aastal, osalejad Astrid Tuisk, Pille Niin ja Andres Korjus. Muu pärimuse hulgas talletati ka siis mõningal määral rahvameditsiini puutuvat, kuid antud artikli käsitlusest jääb see materjal välja. Selgemalt tulevad kogukondades toimunud muutused esile pikema ajavahemiku möödudes. 
on kõrgkoolist saadud ettevalmistus ja ühiskonna ametlik tunnustus, rahvameditsiin põhineb aga kogukonna või perekonna pärimusel, empiirilisel kogemusel, üleloomulikul ilmutusel. Tänapäeval kasutatakse termini rahvameditsiin kõrval ja asemel ka nimetusi etnomeditsiin, pärimusmeditsiin jm (vt Rorbye 2003, 12).

Rahvameditsiini mõistet on püütud defineerida juba alates 19. sajandist. Saksa etnoloogia ja folkloori sõnaraamat "Wörterbuch der deutschen Volkskunde" annab seletuse: "Rahvameditsiin on kõikide rahva seas käibivate haiguskäsitluste ja haiguse vastu kasutatavate ravimeetodite kogum" (Erich \& Beitl 1974, 900). Edaspidi on eri uurijad definitsiooni täiendanud-täpsustanud. Ka WHO tundis organisatsiooni töö selguse mõttes vajadust rahvameditsiini defineerida ning sõnastas selle 2005. aastal järgmiselt: "Rahvameditsiin on eri kultuuridele omastel seletatavatel või mitteseletatavatel teooriatel, uskumustel ja kogemustel põhinevate teadmiste, oskuste ja praktiliste meetodite summaarne kogum, mida kasutatakse nii tervise hoidmiseks kui füüsiliste ja psüühiliste haiguste ennetamiseks, diagnoosimiseks, leevendamiseks ja raviks" (WHO 2005, 1, vt lähemalt Tupits 2009, 17-26).

Eesti pärimusekogujad on läbi aegade suuresti lähtunud Jakob Hurda rahvaluulekogumise printsiipidest: vanema pärimuse eelistamine, variantide kogumine, territoriaalse ammendatavuse nõue, kogumistöö temaatiline suunamine, võimalikult murdekeelsed kirjapanekud jne. Jakob Hurda kogumisprintsiipidest lähtudes on Eesti folkloristid erinevalt mitmete teiste maade ametivendadest tänini kogunud-uurinud ka rahvausundit ja kombestikku (vt Hiiemäe 1989, 310-314), sealhulgas mõistagi rahvameditsiini ainest. Eestimaale Soomest levinud geograafilis-ajaloolise uurimismeetodi rakendamise puhul jäid pärimusetundja ja -koguja isik enamasti tagaplaanile - huvituti eelkõige pärimusteadetest (vt nt Suojanen 1999, 71-72). 1927. aastal loodud Eesti Rahvaluule Arhiivis oli kogumistöö haare võrdlemisi lai, ulatudes kaugelt üle poeetilise folkloori piiride. Tähelepanu juhiti puht-teksti talletamiselt kontekstile, esitusele, folkloorikandjale jm (Loorits 1940, 44-45). Seevastu nõukogude perioodil jäid Eesti folkloristid rahvaluulekogumises enam tekstikeskse minevikku-suunatud lähenemise juurde, olles paljude aastate jooksul ära lõigatud oma teadusharus maailmas toimuvatest muudatustest ning saades Lääne-Euroopas ja Ameerika Ühendriikides tehtud uurimustest aimu vaid kaudsetest allikatest. 
Ka rahvaluule mõiste ametlik kitsendamine soosis tekstikeskset ja poeetilist pärimust (vt nt Kõiva 1990, 452). Eesti pärimusekogumine oli ühelt poolt nõukogude folkloristika ja ametliku tsensuuri mõju all (nt rahvausundi kogumine polnud sel perioodil aktuaalne, suur osa anekdootidest jäeti arhiveerimata), teisalt ei loobutud kogumistöös päriselt Jakob Hurda ja ERA-aegsest etnoloogilisest suunast. Pärast nõukoguliku ideoloogia surve taandumist 1980. aastate lõpupoole avardusid oluliselt uurimis- ja kogumisvaldkonnad. Aktiivsemalt hakati koguma mingi sotsiaalse grupi pärimust (vt nt Korb 2005, 11-13), sealhulgas pöörati enam tähelepanu ka tegutsevate teadjate - rahvaarstide, ennustajate jt - küsitlemisele-filmimisele (vt Kõiva 1997). Niisiis on Eestis rahvameditsiini uuritud enam viimase 30 aasta vältel ning Eesti uurijad on käsitlenud seda sageli konkreetse paikkonna või kogukonna teadmisena. Teisalt ei saa "oma" ja "võõra" vahele rangeid piire seada, sest läbi aja on toimunud oma ja laenuliste rahvameditsiini praktikate segunemine (Korb 2006, 103-104; Tupits 2009, 23).

\section{Rosalie Ottessoni rahvameditsiini-alase teabe kogu kujunemine}

Tänu tollase rahvaluule osakonna Siberi kaastöölise Rosalie Ottessoni (eluaastad 1899-1979) kogumistööle on ERAs nõukogude päevist ligi 3000 lehekülje suurune pärimusekogu Ida-Siberi eestlastelt. Rosalie Ottesson kogus pärimusainest oma viimasel elukümnendil ajavahemikus 1969-1975. Tõuke kogumistööks sai naine tolleaegselt Moskva ülikooli etnograafiatudengilt Igor Tõnuristilt, kes külastas piirkonna eesti ja läti külasid 1965. aasta suvel, kui viibis Krasnojarski krai lõunaosas arheoloogilistel välitöödel. Rosalie Ottesson osutus Igor Tõnuristile tänuväärseks informandiks, kellega hiljem suheldi kirja teel.

Rosalie Ottesson kasvas üles traditsioonilises rikkaliku rahvapärimusega külakogukonnas, kus vanad jutud, laulud, loitsud, kombed jms olid osa igapäevaelust. Ta õppis kodukülas Ülem-Bulankas neli aastat eestikeelses koolis, 6-klassilise hariduse omandamiseks õppis ta edasi juba vene külas Jermakovas. Seejärel töötas Rosalie mitmel pool apteegiteenija ja juhutöölisena. Ottessoni noorusaastad jäid enamlaste võimuletuleku ja sellele järgnevasse aega, mis tõi ka Siberi eestlaste ellu suured muutused. Aktiivse eluhoiaku ja heade 
Rosalie Ottesson umbes 70 aastasena (ERA, Foto 9752).

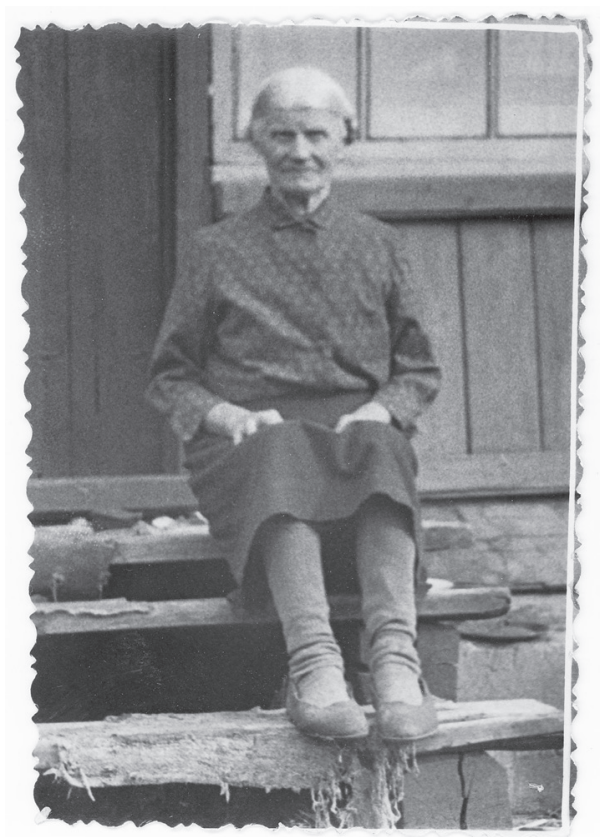

organisaatorivõimetega Rosalie Ottesson värvati kommunistliku partei liikmeks ja suunati Krasnojarski parteikooli. Ta võttis suuresti omaks tol ajal valitseva nõukogude ideoloogia. Ottesson töötas partei suunamisel kodukülas lugemistoa juhatajana, Karatuzskoje (Karatusi) rajooni naisorganisaatorina, aitas kolhoose organiseerida, töötas kooliõpetajana ja osales aktiivselt ühiskondlikus elus. Ottesson uskus ilmselt siiralt, et nõukogude kord toob inimeste ellu rõõmu ja õitsengu. Ta võitles aktiivselt küla kultuurielu edendamise eest. Rahvaluule osakonnale kaastöö tegemises nägi Ottesson võimalust eneseteostuseks, ka tahtis ta tunda end ühiskonnale vajalikuna (vt lähemalt Korb 2013, 15-16; Korb 2015b, 25-30).

Rahvameditsiini käsitlev aines moodustab Rosalie Ottessoni kogutust tegelikult suhteliselt väikese osa (lehekülgede koguarvult umbes 5\%), kuid on väga kõnekas. Rikka rahvatraditsiooniga külakogukonnas, mille liikmete hulka Ottesson kuulus, olid arstimisloitsud, rahvapärased ravivõtted ja -viisid osa traditsioonilisest kogukonna pärimusest, seega osa rühma kultuurimälust (vt Assmann 2012, 1776-1777). Rosalie Ottessoni eluajal oskas tema kodukülas 
ja naabruses asuvas Ülem-Suetukis peaaegu igaüks teatud hädade puhul abi anda. Ka tegutses Siberi külades Ottessoni kaastöö tegemise ajal üksjagu rahvaarste, keda inimesed usaldasid ja kelle poole häda korral pöörduti. Samas oli juba mõnevõrra varem toimunud riikliku meditsiini võidukäik: antibiootikumide järjest laialdasemat levikut ja neile omistatud lausa imettegevaid omadusi peetakse rahvameditsiinist eemaldumise üheks põhjuseks (Kleinman 1980, 2; Kõiva 1995, 178). Siberi eesti küladesse olid Teise maailmasõja eelsel või selle järgsel ajal jõudnud koolitatud velsker-ämmaemandad, kes olid üldjuhul võõrad - vene vm rahvusest ega osanud eesti keelt. Tunnen üht Ülem-Suetuki külast pärit naist, kes taotles pärast meditsiinikooli lõpetamist kohta koduküla velskripunktis, kuid ta suunati nimme tööle kodukandist kaugele vene külla. Siberi rajoonikeskustesse rajati pärast Teist maailmasõda haiglad, tõsisemate terviseprobleemide puhul hakati inimesi järjest enam haiglasse saatma. Sünnitus muudeti kodusest sündmusest haiglasündmuseks. Siberi eestlaste mälestused möödunud ajast juhivad tähelepanu asjaolule, et lapse või ema surm sünnitusel, eriti juhul, kui naist ei jõutud haiglasse viia, võis lõppeda kohalikule velsker-ämmaemandale vangistusega (vt nt Korb 2010, 91). Samas usaldasid inimesed koduküla ravitsejat tihtipeale enam kui raviasutust või võõrast koolitatud meditsiinitöötajat. Paljude vanemate külaelanike vene keele oskuski polnud tol ajal ladusaks suhtluseks piisav. Samas oli ravitsejate tegevus Nõukogude Liidus keelustatud ja karistatav kuni 1980. aastate alguseni, mil Leonid Iljitš Brežnev andis rahvaarstidele tegutsemiseks vabad käed (Kõivupuu 2000, 172). Tegelikult ei sattunud Siberi eestlastest arvukad ravitsejad nõukogude võimu päevil samaväärse surve alla nagu Siberi põhjarahvaste šamaanid. Viimased kuulutati usukultuse teenriteks ja rahvavaenlasteks: nad rikastuvat teiste arvelt ja ravimise asemel kahjustavat inimesi. Šamaanidelt võeti ära rituaalsed esemed, nad vangistati või küüditati (Vallikivi 2005, 41). Ravitsejate tegevus külades polnud samavõrd nähtav ja atraktiivne kui šamaanide oma, kuid teadmine ravitegevusele järgneda võivast karistusest avaldas paratamatult pärimuse edasiandmisele mõju. Eesti rahvaarste ja meediume uurinud Mare Kõiva tõdeb, et rahvameditsiini ja -arste soosivad ajad saabusid siis, kui rahvapärase arstimise järjepidevus oli jõudnud enamikus Eestimaa paigus katkeda (Kõiva 1995, 183). Õigeusklike naabrite mõjuväljas kasvanud Siberi eestlaste sõnamaagia tundmine oli siiski märksa laiemalt levinud kui Kodu-Eestis. 
Pärimusrühma/pere liige omandab mingi osa rahvameditsiini teadmistest pärimuslikul teel. Minussinski piirkonna eestlaste pärimusrühmas antakse ravisõnu ja -oskusi edasi samuti nagu muudki pärimuslikku teavet, näiteks laule, jutte, kalendritavandit (vt ka Templing 2005, 215). Muidugi võib igast kogukonnast leida võimekamaid ja vähem võimekaid rahvaravioskustega inimesi, sama võib öelda ka rahvajutustajate, laulikute või traditsioonilise kombestiku tundjate kohta. Loitsutekstide samastamist kõigile soovijatele kättesaadava jumalasõnaga kohtab Siberi eestlaste vanemates külades üpris sageli (vt Korb 2006, 93-95). Arstimissõnade samastamist jumalasõnaga tavainimeste hulgas mõjutab ilmselt asjaolu, et aastasadu on Euroopa kultuuriruumis loitsudena tarvitatud evangeeliumide ümberkirjutusi, palvetekstide osi jms (Kõiva 1998, 200). Loitsutraditsiooni on aegade jooksul lisandunud erineva taustaga kristlikke tekste (Kõiva 1992, 119-123). Loitsuna on kasutatud ka meieisa palvet, mis pidi stabiliseerima igasuguse kriisiolukorra (Kõiva 1999, 118).

Nõukogude päevil koguti eeskätt ideoloogiliselt sobivamat pärimusmaterjali. Rahvameditsiin jäi pigem kogumistöö äärealale: folkloriste-uurijaid oli tookord märksa vähem kui 21. sajandi algupoole, aktiivsemalt uuriti neutraalsemaid teemasid: rahvalaulud, kalendritavand, lühivormid (mõistatused, vanasõnad, kõnekäänud).

Arhiivi kaastöölised läkitasid arhiivile eeskätt materjali, mida neil paluti saata. Rosalie Ottessonile saadeti kogumistöö hõlbustamiseks "Rahvapärimuste Koguja" (RPK) numbrid 2-10 ja paluti järgida seal leiduvaid küsitluskavu. Rahvameditsiini-alased küsimused on selles valimikus esindatud põgusalt, muude küsitluskavade (nt rahvakalendri tähtpäevad, surmaended) osana.

Herbert Tampere koostatud "Üldisi juhiseid rahvapärimuste kogujale" (RPK 5, 3-8) on küll muuhulgas mainitud ka sõnamaagia kogumise vajadust, kuid täpsemaid juhiseid selle talletamiseks ei anta. Lähemalt on "Rahvapärimuste Kogujas" leidnud käsitlemist ravimtaimedega seonduv - Gustav Vilbaste "Rahvapärasest botaanikast" (RPK 6, 52-58). Samas Erna Normanni koostatud küsitluskava "Küsimusi lausumissõnade alalt" raviloitse peaaegu ei käsitle, küsimused seonduvad põhiliselt majanduse, eeskätt loomakasvatusega. Loitsude küsitluskavale on ajastuomaselt lisatud: "Lausumissõnad on kadunud koos rahva hariduse ja teadmiste süvenemisega. Õige vähene osa on säilinud kas laste laulukestena või ühenduses mõne töökombega, kusjuures neil muidugi ei ole 
enam maagilist tähendust" (RPK 3, 35). Seega püüti jätta mulje, et soovitakse teateid minevikus toimunu kohta. See sobis ka tolleaegse rahvaluulekäsitlusega: rahvaluule kui minevikuline nähtus, rahvaluulekogumine kui "vanavara" päästekogumine. Rahvameditsiini kogumisega seonduvad veel Rosalie Ottessonile rahvaluule osakonna töötajate saadetud küsitluskavad "Paha silm" (18.08.1969) ja "Küsitluskava matusekommetest" $(23.05 .1972)^{3}$. Meditsiinilise haridusega Mihkel Kase ja Kaljo Villako koostatud põhjalikum nõukogude perioodil ilmunud rahvameditsiini-alane küsitluskava ${ }^{4}$ ilmselt Rosalie Ottessonini ei jõudnud.

Kui Ottesson saadetud küsitluskavu eeskujuks võttes materjali saatis, sai ta kiita: Tore, et Te olete hakanud "Rahvapärimuste Koguja” küsitluskavu ja juhendeid silmas pidama. See on ka andnud häid tulemusi (kiri: märts, 1970).

Samas saatis Ottesson rahvameditsiini-alast teavet ka omaenda teadmiste põhjal. Ühe osa oma korjandustest on ta pealkirjastanud "Mismoodi Ülem-Bulanis endisel ajal haigusi arstisivad?" (Arvele võetud 20. aprill 1970. a. Nr. 96.) Ta kirjutab:

Tsaarivalitsuse aegu arstisi oli vähe kuigi neid oli, siiski nad olivad küladest kaugel, igakord oli neid raske kätte saada. Tihtilugu puudusivad ka arstirohud. Inimesed tarvitasivad hädaajal oma koduseid ja metsarohtusi, lausumisi ja igasuguseid ebakombeid, mis veel tänini liikel on. Ma sellest jutus tarvitan prostoi ${ }^{5}$ sõnu nagu meil ÜlemBulanis rahvas räägib. Ärge aga pahaks pange. (RKM II 271, 505)

Nü̈̈ paar sõna, mismoodu enne inimesed arstisivad haigusi: Loeti inimese haige peale kolm korda ilma hinge tõmbamata, puhuti peale ristipidi. Lugejal pidid hambad suus olema, räägiti, et see kes ilma hammasteta on, selle lugemine ei aita. [---] Kirmi ${ }^{6}$ sõnad olivad niisugused: ussikene hulluke, matsikene maoke, mis sa mind nipid, mis sa mind näpid. Mine metsa puu juura närima ja haava koora imema. Peale selle lugeja näris, haigel hammastega seda kohta, kus kirm oli. (RKM II 271, 103-104)

${ }^{3}$ Eesti Folkloristika Ajaloo materjalid (EFAM) Rosalie Ottessoni korrespondendi kaart.

${ }^{4}$ Avaldatud ajakirjas Nõukogude Eesti Tervishoid 1959. aastal. Rahvameditsiini sisaldavate küsimuskavade kohta vt Tupits 2009, 161-219.

${ }^{5}$ Lihtsaid (vn).

${ }^{6}$ Nakkuslik kurguhaigus. 


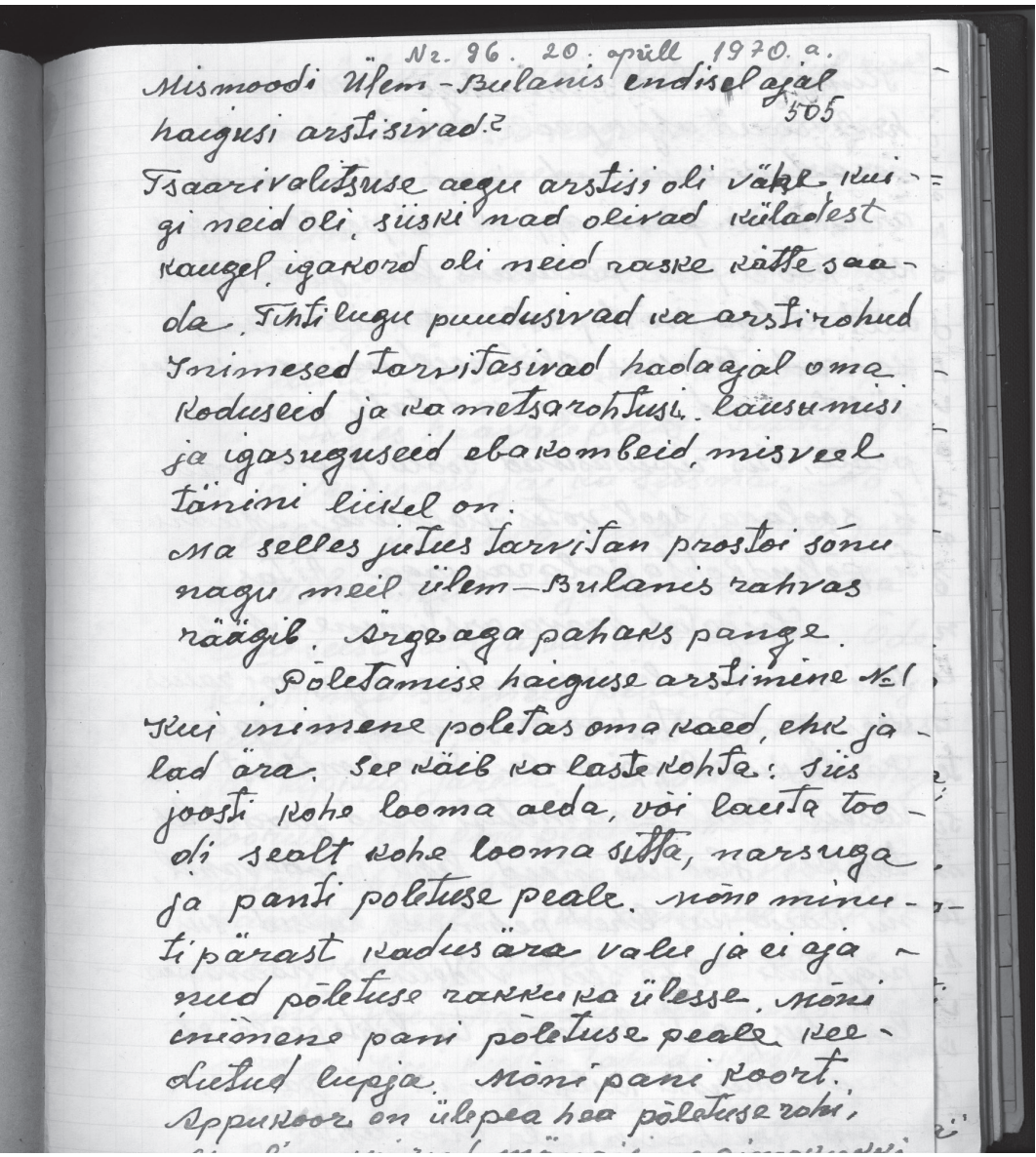

Rosalie Ottessoni käsikiri (RKM II 271, lk 505).

Rosalie Ottesson tundis nähtavasti rahvameditsiini materjale saates enese rehabiliteerimise või kaitsmise vajadust, sest lisas oma saadetise juurde:

Nüüd nõukogu valitsuse aegu, inimesed neid lugemisi ei usu, iga haigusega pööravad arsti poole. Meil nü̈̈d igas külas on arst, kaugele pole vaja sõita, on inimene haige, ei jõua oma jalaga haiglasse minna, tuleb arst kodu. (RKM II 271, 103-104) 
Nõukogude korra saavutusena tõi Ottesson oma saadetises esile ka lapse sünni ja registreerimisega seonduva:

Meil naisterahvas enne sünnitamist viiakse Motorski sünnitusmajasse. Peale sünnitamise hoitakse teda seal 8-10 päevani ja veel rohkem, see rippub naisterahva tervisest ära. Arst teatab sellest mehele, millal tuleb naise ja lapse järele sõita. Enne kui naist ja last arsti käest kätte saada. Isa ja ema arstide juuresolekul annavad lapsele nime, siis mees läheb külanõukogusse registreerib lapse ära toob nõukogust lapse mitriku, näitab teda arstile, arst viib mitriku järele laps nime bolnitsa ${ }^{8}$ raamatusse sisse. Annab isale mitriku tagasi. Annab arstile altkirja, et ta oma naise ja lapse sai tervelt ja elusalt kätte. (RKM II 271, 399)

Tookordne nõue registreerida laps enne haiglast väljasaamist pidi tõenäoliselt aitama vältida piirkonnas varem levinud praktikat, kus kodus sünnitanud naised registreerisid lapse sünni mitu nädalat või isegi kuid toimunust hiljem. Põhjuseks ilmselt, et paberitega seotud asjaajamist ei peetud esmatähtsaks, meelitas ka võimalus kauem pärast lapse sündi tööst eemal olla. Vestlusest Minussinski piirkonna vanemate inimestega selgus, et paljude inimeste tegelik sünniaeg ei kattu dokumentides olevaga (vt nt Korb 2010, 278-279).

Tõenäoliselt esitasid rahvaluule osakonna töötajad Rosalie Ottessonile saadetud rahvapäraste haigusseletuste, raviviiside ja loitsude kohta ka küsimusi, mispeale ta vastas:

(Arvele võetud 17. sept. 1969. Nr. 134.)

Lp. Proodel! Teie küsimuste peale seletan ma vähe laiemalt. Kõigepealt räägin roosist ${ }^{9}$. Roosa on üheksat seltsi. Roos hakkab inimese külge vihastamise ja ehmatamise pärast. Roosa arstiti ja ka praegu arstitakse nii: Võetakse süsimusti talle villu, nende tallevillade peale pannakse ära küpsetatud ussi raasukesed, need villad ühes ussiga pannakse roosi peale, siis võetakse sinine paber, olgu või vihiku kaan, kui ta aga sinine on. See paber kriipseltakse risti ja rästi kriidiga ära, pannakse ta villade peale, nii et kriidi pool on vastu villasi, siis seotakse ta punase närtsuga kinni, see ka aitab. On ka roosi vastu sõnad, loetakse roosi peale. Ka aitab. Roosi märjaks ei tohi teha, siis enam arstimine ei aita, roos narõvaita $b^{10}$ - kui arst teda lahti ei lõika, roos teeb üheksa haava selle kohale, kus ta on. Roos tüdrukutele lööb

${ }^{7}$ Siin: sünnitunnistuse.

${ }^{8}$ Haigla (vn).

${ }^{9}$ Naha- ja limaskestade lümfiteede põletik.

${ }^{10}$ Hakkab mädanema (vn). 
silmnäosse, naisele rinda, aga meisterahvale käsivarde või reide. Suuremjagu ta niimoodu lööb. (RKM II 271, 147)

Ottesson saatis arhiivile veel arstimissõnad kõhuvalu, hambavalu, sügeluse, veiseröögatuse ${ }^{11}$, odraiva, paise, köha, valu jm vastu. Saadetud loitsude eest sai ta kiita. Järgmises kirjas (dateeritud 19.08.1969) esitati talle küsimusi paha silma mõjujõust, aga ka neutraalsemal teemal - ravimtaimede kasutamise kohta. Ottesson vastas kirjale:

Meil enne ja ka nü̈̈d inimesed korjavad metsarohtusi, lillesi, puu koora, pungasi kasutasivad rohuks ja praegu veel kasutavad, mitte üksi inimeste jaoks, vaid ka loomade jaoks. Ja mina ise ka neid kasutan, saab abi. (RKM II 271, 153)

Ühes oma järgmistest saadetistest tutvustas Ottesson lähemalt Siberi puude kasutusvõimalusi ja raviomadusi.

Jutt puudest. Meil siberis kasvavad igasuguseid puid. Kased, männid, kuused, lisvenid ${ }^{12}$. Haavad, Kedrad ${ }^{13}$. Kõik nad on kõlbulised ehitamiseks ja ka kütiks. Neist võib ka muid aineid tarvitata. Kasest kevadel saab mahla, suvel saab mähka. Männist tehakse skipitaari ${ }^{14}$ Inimesed teevad männi koordest ja okstest omadelle vanni kui jalad kõvasti valutavad. Panevad männi oksad ja koored kogu nõeldega patta keedavad neid ummukses. Kui on juba kovasti punane seis lasevad ta jahtuda parajaks, tostavad tema suure taasi $i^{15}$ või pütti, ja inimene läheb poolest kehast saadik sisse. Joob ka seda vett, jala ja käe valu kaob ära. Kedra vaik kõlbab seeraks ${ }^{16}$. Inimesed korjavad kedra küllest vaigilisi korpaid sulatavad siis mäluvad neid. Ka lisveni korbastest saab seerad. (RKM II 271, 423)

Sageli esitas Rosalie Ottesson rahvameditsiini-alase teabe omakogemusliku jutuna, näiteks:

Nü̈̈d räägin mis minuga juhtus kui ma alles 17aastane olin: Elasin siis Ülem-Soetukis. / soetuk - on ka eesti küla / Elasin oma õe juures. Ühel öösel järsku ajas mind külmetama, ja paremal pool lõuaperas põsepool alumise hamba kohal algab valu, minu arvates oli, et mul alumine kihv valutab, mida edasi, seda ikka kõvemini.

${ }^{11}$ Sammaspool (nahahaigus).

${ }^{12}$ Lehised (vn).

${ }^{13}$ Seedrid (vn).

14 Tärpentini (vn).

${ }^{15}$ Pesukaussi (vn).

${ }^{16}$ Seera on tuntud Siberis närimiskummina. 
Kogu silmnägu hakkas punetama ja valu ikka suuremaks. Hommikul õemees G. J. rakentas täku saani ette ja viis minu haiglasse oli meilt$35 \mathrm{~km}$. maat. Jõutsime haiglasse - arsti küsimise peale vastasin - et mul hammas valutab. Missugune hammas? Küsis arsti P. A. Näe see hammas, näitasin näpuga oma alumise hamba peale. Arst vaatas ja vaatas, pärast ütles: "Hambad sul kõik on terved, ühelgi pole hauku, nad ei või sul valutata, võib olla on sull miskid muu häda?" - "Ei ole... hammas valutab, vastasin ma läbi pisarate, antke hamba rohtu, või tõmmake välja." Arst vaatas jälle mu hambaid, vaatas mu silmnägu. Jah, lõug on punane paistes, aga mispärast ei tea. Mina aga rääkisin oma, et mull hammas valutab. Arst tõstis juba kaks korda hamba tangid, ise nii kahtlane - räägib, minu arvates, see hammas sul ei valuta, võib olla teine hammas sull valutab sa ei saa aru. No. P. A. vaata siis ise missugune hammas mull valutab: Sa oled jo arst! P. A. vaatas jälle uиеsti ja ütles: "Ничего я не вижу17". Ma ise seekord venekeelt ei osanud, ütlesin oma keeles: "Oled küll arst, aga lollim kui mina, ma tunnen ära missugune hammas mul'valutab, aga sa ei tunne," õemees oli mul'vahelträäkija, muidugi viis mu sõnad arstile üle. Arst ilma sõna lausumata võtis hambatangid, võtis minu pea oma kaenlasse ja tõmmas minu terve hamba kogu hingeme tükkidega mu suust välja, andis ta mu kätte ja sõnas, "vot nah siss ta on". Ise pani tangid käest ära, läks ja pesi oma käetki puhtaks. Vot siis alles algas valu, kõik ilm lõi mu ees mustaks, peaaegu pidin kukkuma. Mis muud, kord hammas välja tõmmatud, hakka minema. Enne kui koju jõutsime, paistetas mu nägu ära, suu viltu, silmad peaaegu kinni paistetand. Kange valu. Kodu väravas ei ootand ma enam millal õuevärav lahti tehti, et hoovi sõita, hüppasin saanist välja ja jooksin tuppa, ukse tuli õde G. L. vastu, vaatas mulle näkku ja kiljatas: "Oi Jumal! Roosi, sul' on silmnäos punane roos". Ma vastasin "Mis kuradi roos arst tõmmas mul hamba välja. Nü̈̈d ma varsti suren”. Ma see aeg ei teatnud nendest roosidest aimugi. Roos jah, vastas õde. Mine kohe N. M. ta oskab roosi sõnu, loeb peale, saab terveks, kui jätad kauaks, lööb lahti ja rikub su silmnäo ära, roos võib su näosse üheksa haava teha. N. M. elas meist ületee naabruses. Ma pöörasin ukse juurest kohe tagasi N. M. juure, lähen tuppa N. M. vaatab mulle näkku ja sõnas: "Oi Roosi, sull silmnäos punane roos, millal sa nii kõvasti vihastasid, või ehmatasid, et sulle roos põske lõi?” Ei tea... Arsti muidu suren. N. M. pööras minu silmnäo vasta hommikut luges ja puhus peale, siis võttis tassiga vett, luges vee peale lasi selle vee mull ära juua, siis käskis mind voodisse heita, et kui poole tunni pärast valu ei kao ära siis loeb veel kord. Poole tunni pärast valu silmnäost oli kadunud ja ma uinusin magama, tundi kolm ma magasin. See aeg kellasi ei olnud, kõik arvestasid siis päeva järgi. N. M. ütles, et ma nii kõvasti magasin, et kohe norskasin. Paistus näost hakkas alanema, aga valu

${ }^{17}$ Ma ei näe midagi (vn). 
ei olnud enam sugugi. N. M. veel kord luges, õppetas mulle ka need sõnad, sest ajast saadik ma neid roosi sõnu ka ise olen palju kordi inimestele, roosi peale lugenud, on aitanud. On see siis nõidus või ei ole, ma ei tea. (RKM II 271, 147-150)

Ottessonile oli nõukogude võimu perioodil õpetatud usu ja vanade tavade-kommete salgamist, samas olid need talle lapsepõlvest tuttavad ja külakogukonnas juurdunud. Rosalie Ottessoni kahetine positsioon - külaelanikega sarnane pärimuslik taust ja vastukaaluks nõukogude võimu ideoloogiline surve ja töö nõukogude võimu teenistuses - iseloomustab ka tema saadetisi. Samas väärib Ottessoni kogumistöö tunnustust juba seetõttu, et ta oli nõukogude võimu perioodil ainuke arhiivi kaastööline Siberist, kes jäädvustas sealsete eestlaste rahvameditsiini-alast jm teavet.

\section{Eesti Rahvaluule Arhiivi kogumismatkad aastatel 1991 ja 1992}

ERA kogumismatkad Minussinski piirkonna eestlaste juurde 1990. aastail toimusid suuresti muutunud oludes: Eesti Vabariigi taastamisega seoses avardusid folkloristide kogumis- ja uurimisvaldkonnad, ka võimalused maailma folklooriuurimustega kursis olla. Siberi kogumistöö alguses võis Eestiski täheldada muutusi uurimisparadigmades: folkloori ei käsitletud enam minevikupärandina vaid kui mistahes sotsiaalse rühma pärimust. Folkloori liigikeskne määratlus loovutas koha funktsionaalsele, rõhuasetus siirdus pärimusteoselt inimese ja toimiva kollektiivi mõistmisele (Hiiemäe 2002, 281; Korb 2005, 11-13).

Siberi eestlastele tõid 1990. aastad kaasa keerulised majandusolud: lagunesid ühismajandid, valitses terav tööpuudus. Külade elanikele pakkus äraelamisvõimalust isiklik loomakasvatus ja põllupidamine. Ülikiire inflatsiooni tingimustes vähenes suhtlus Eestimaa sugulastega. Samas Eestis taastati/tekkisid võimalused taotleda kultuurifondidest välitööde läbiviimiseks rahalist abi. Eesti Rahvaluule Arhiivi tehniline varustatus oli neil aastail äärmiselt vilets, heli- ja videosalvestusi saime teha väga piiratud hulgal.

Et rahvaluulekogujatel ${ }^{18}$ puudusid eelteadmised piirkonna külade elanike arvust ja pärimuse hetkeseisust, oli 1991. aasta suvel

18 1991. a Siberi välitöödel osalesid Anu Korb ja Astrid Tuisk. Kogutu arhiivis RKM II 447, 216-537. 
Siberi eestlaste juures kogetud elav ja rikkalik pärimus meile ootamatu, samas meeldiv üllatus. Ülem-Suetuki külas elas siis umbes 300 inimest, kes kõik oskasid eesti keelt. Ülem-Bulankas elas veel paarkümmend peret, eesti keelt räägiti neist pooltes.

Kuna Eesti välitöötraditsioon oli olnud pikka aega minevikku suunatud, külades oli palju heade pärimusteadmistega eesti keelt kõnelevaid inimesi, keskendusime esmalt rikkaliku vanema traditsiooni kogumisele. Eneseõigustuseks ka asjaolu, et mitmete vanemate eestlaste küsitlemiseks ei pruugi edaspidi võimalust avaneda. Esimese Siberi-külastuse järgselt 1991. aasta sügisel koostasin projekti "Rahvuskultuur Siberi eesti asundustes", esialgu finantseerimiseks vastloodud Eesti Rahvuskultuuri Fondile (vt Korb 2005, 19). Fondi rahalisel toel toimus 1992. aasta talvel samasse piirkonda teine kogumismatk, nüüd juba nelja-liikmelise seltskonnaga ${ }^{19}$ Kogusime võimalikult mitmekesist materjali: laule, jutte, rahvausundit, kombestikku jne, sealhulgas ka rahvameditsiini puutuvat teavet.

Rahvapäraste ravimisviiside ja -võtete kasutamine oli 1990. aastail Minussinski piirkonna eesti kogukondades pärimusrühma ühisteadmine: ravitsejad kogukonnas eriliselt esile ei tõusnud, sest oskused ja ravisõnad arvati olevat igaühele kättesaadavad ja õpitavad.

Taluperedes omandati olulised oskused eluga toimetulemiseks enamasti teismelise-eas. Nende teadmiste hulka kuulusid ka rahvapärased ravimisviisid-võtted. Osa inimesi on oma oskusi ka koheselt kasutama hakanud, seega on teateid ka noortest ravitsejatest (vt nt Templing 2005, 214, 226). Külakogukonnas levinud tavaarusaam eeldas teadjalt siiski soliidset iga. Näiteks Eesti andmed 1929. aastast näitavad, et suuremal osal ravitsejaist oli vanust üle 40 (Rooks 1929, 378). Ühelt poolt oli noorel teadjal oma vähese elukogemuse tõttu traditsioonilises külakogukonnas raske end maksma panna, teisalt ei olnud uuele ja moodsale avatud noored alati ise valmis ravitsejana tegutsema (vt Korb 2006, 96). Mitmel puhul avaldasid vanemad kogukonna liikmed arvamust, et: noored enam ei usu neid sõnu, mõni usub ka, aga vanad usuvad küll kõik (RKM II 447, 350 (14)).

See kinnitab kollektiivse mälu teooria paikapidavust - minevikust jääb alles vaid see, mida tahetakse ja suudetakse rekonstruee-

19 1992. a välitöödel osalesid Anu Korb, Astrid Tuisk, Kadri Peebo (Tamm) ja Ain Urbel. Käsikirjaline materjal on arhiveeritud köites RKM II 449, 1-671, lisaks tegime 18 tundi heli- ja 2,5 tundi videosalvestusi. 


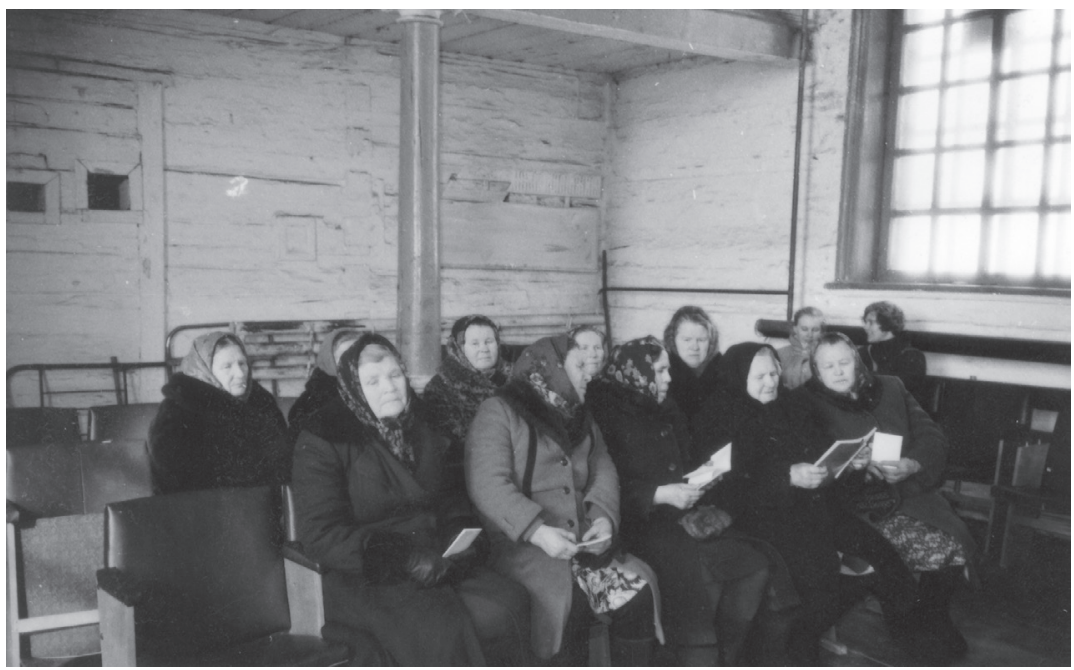

Ülem-Suetuki rahvas kirikus. Kadri Peebo foto 1992 (ERA, Foto 15020).

rida (vt nt Assmann 2012, 1780-1782). Tihtipeale hakati rahvameditsiini oskusi hindama alles siis, kui endal lapsed kasvamas. Üks Ülem-Suetuki naine selgitas oma ravioskuste omandamist:

Mul esimene laps sündis tütarlaps. Kui vähe miskit oli, lõi roos rinda. Käisin vanaema juures. Ta ütles, et õpi ise need sõnad ära. [---] (RKM II 447, 232-233 (40) < naine, 71a.)

Vanemad kogukonna liikmed olid aga mõistagi huvitatud oma teadmiste edasiandmisest. Paljud arvasid, et:

Sõnu edasi anda võib küll. Las noored õpivad ja loevad. Mina olen nii paljudele õpetand ja olen lugend, ükskõik, aitab! See on vale jutt, et ei tohi teisele anda. Ta on ju jumalasõna ja aitab ikka. (RKM II 447, 239 (55) < naine, 71a)

Mitmed külaelanikud olid ravisõnu oma tarbeks üles kirjutanud ja lubasid meil need lahkesti kopeerida. Jumalasõnaks peeti ka taevakirju ${ }^{20}$, mille kaitsetoimesse kindlalt usuti. Need olid väga

${ }^{20}$ Taevakiri (ka taevaraamat, Neitsi Maarja unenägu vms) on pärimuse kohaselt taevast saadetud või alla visatud üleloomulike omadustega kaitsekiri, mis sisaldab ka tsitaate piiblist. 


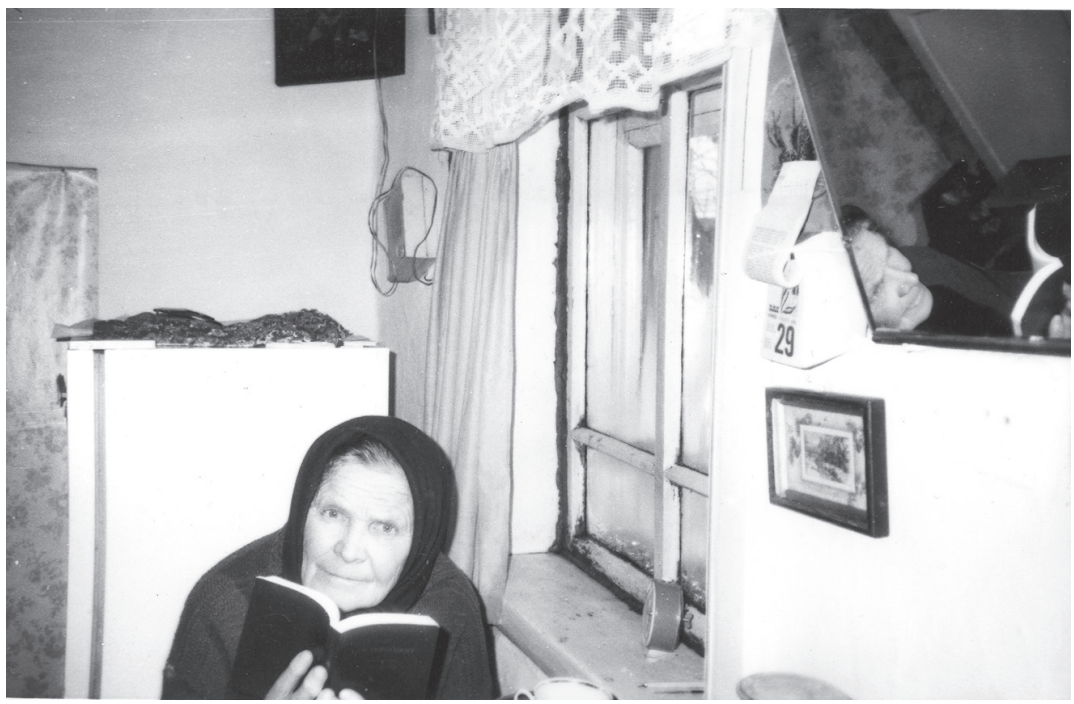

Juhanna Paap: Sõnu edasi anda võib küll. Las noored õpivad ja loevad. Kadri Peebo foto 1992 (ERA, Foto 15043).

paljudes peredes tallel ja taevakirja kandsid kaasas teekäigul, tööl vm kodunt eemal ka nooremad kogukonna liikmed.

Usuelu oli Venemaal alates perestroika-järgsest perioodist ametlikult lubatud, tänu sellele ka suuresti elavnenud. Siberi külakogukondades samastati 1990. aastail nagu varasemalgi perioodil raviloitse kõigile kättesaadava jumalasõnaga.

Iga haiguse vastu on jumalasõna lugemine. Ega ühe korraga millalgi eaks ei saa, peab ikka kolm korda lugema. (RKM II 447, 449 (9))

Mõned naised ei tahtnud siiski rahvameditsiini puutuvail teemadel vestelda abikaasa kuuldes. Naine, kes teadis roosi-, nikastuse-, valu-, ussisõnu ning mitmesuguseid kunste põllu- ja aiapidamise tarvis, muutus märksa jutukamaks, kui tema abikaasa läks õue loomi talitama. Mehele ei pidanud need nõiduse jutud meeldima.

Üldiselt aga arvati, et eestlaste seas nõidu ei ole, on vaid ravitsejad:

Ega sie ei ole nõidumine, sie on arstimine. Tasu ei ole vaja tahtagi.

Tänada - seda ka ei ole vaja. (RKM II 447, 334 (8)) 
Nõidu arvati enam olevat venelaste seas, nemad teadvat ka rohkem mitmesuguseid kunste. Näiteks Volklova vanamutt ravinud vahaga valades pealepandud häda. Ka eestlasi käinud seal abi saamas, tõhusamalt mõjunud käimine vana kuu otsas ja noores kuus. Mõistagi jõudis paljurahvuselises ümbruses elavate Siberi eestlaste traditsiooni ka naabritelt laenatut. Näiteks eestlanna Anni, kes roosi-, nikastuse- ja hambavalusõnade tundmise kõrval oskas ka ehmatusest saadud hädasid ravida, olevat oma tarkused saanud vene naiselt, kelle juures oma pojaga ravil käinud.

Mõned inimesed arvasid siiski, et arstimistarkusi võib õpetada vaid endast noorematele:

Endast vanemale ei saa õpetada, ei aita. Siis enam sinu sõnad ei aita. (RKM II 447, 400-401 (54) < naine, snd 1917)

Kuna kogujad olid teadmiste valdajatest nooremad, ei tekitanud probleeme rahvapäraste ravioskuste edasiandmine Eestist pärit kogujatele. Loitsud ja oskused anti meile edasi usus, et me neid ise vajadusel kasutaksime. Külamees, kes kogujale kollatõve ravimist õpetas, jälgis hoolega, et temast vanem naiseõde seda kogemata pealt ei juhtuks kuulma ja sellega tema ravivõimeid ei kahjustaks.

Kindlalt usuti ka, et sünnipärased vead lastel on põhjustatud vanemate eksimustest, ebaväärikast käitumisest või ema ehmatusest lapsekandmise ajal. Mõnele neist hädadest arvati teadjailt abi saavat. Näiteks raviti Ülem-Suetuki külas koeratõbe järgmiselt:

Kui tulised söed olid ahjus, enne leiva panemist, panivad lapse leivalabida peale ja näitasivad nagu viskaks ahju. Siis peab teine küsima: "Mis sa tied?"

"Küpsetan sapaka ${ }^{21}$ staarostit ${ }^{22}$."

"Sabaka staarõi, mine minema!"

Siis oli arstitud. (RKM II 447, 365 (59))

Külades oskasid inimesed naba paika panna, suutsid triikimisega kõhuvalu leevendada, ravisid savi ja kusega paistes jalgu, hõõrusid tuulest tulnud häda vastu keha soolaga, kaotasid soolatüükaid villase lõnga ümber sidumisega, narile ${ }^{23}$ arvati abi saavat, kui esimene laps haiget kohta närib jne. Samuti tunti allikaveega silmade pesemist.

${ }^{21}$ Koer (vn).

22 Vanadus, vana (vn).

${ }^{23}$ Liigestehaigus. 
Heli- ja videoaparaadid olid 1990. aastatel Siberi külaelanikele veel suhteliselt tundmatud. Üksikud külaelanikud, kes jagasid meiega meelsasti oma teadmisi, ei lubanud oma juttu salvestada (vt ka Korb 2005, 82-86). Samas olid mitmed nõus ravivõtete ja ravisõnade edastamist demonstreerima videokaamera ees, kus kord kehastusin ka mina "patsiendiks". Kui keegi päriselt külas abi vajas, toimetati seda kõrvaliste isikute juuresolekuta, vaid patsiendi ja teadja vahel. Küll aga lubati meil filmida "paha silma" vee tegemist. Ja kui minu kaaslane kaebas liigsöömisest saadud kõhuvalu üle, teadis meie perenaine kohe abi - keetis talle koirohu-raudrohu teed.

Tervishoiukorralduse paranemine ja meditsiiniabi kättesaadavamaks muutumine pole ka hästiarenenud riikliku meditsiinisüsteemiga riikides kaotanud huvi alternatiivmeditsiini vastu (Alver \& Selberg 1989, 207). Tänapäevalgi on laialt levinud uskumus, et teatud hädade korral (nt roos, uskumuse kohaselt tuulest, veest, maast või pahast silmast saadud haigus) ei saa riiklikule arstiabile loota. Seda arvamust kinnitab ka Minussinski piirkonna eestlastelt kogutu, nt:

Meil oli siin rajoonis kirurg, ta ise suri ära, neerud olid haiged. Tema juba lõpuotsas ütles, tunnistas, et käige neil vanainimestel, et meie ei saa [roosi vastu] muud teha kui loigata. Nad [arstid] saavad aru küll, aga nad ei taha ennast nii alatuks teha. Näe, roosile ei saa nemad midagi teha. Sie käskis kohe, et minge vanainimestele ja arstige sial. (RKM II 447, 396 (21) < naine, snd 1929)

Külaeestlased pidavat võimalusel hoiduma üldse arsti külastamisest, nenditi, et:

Suetukist keegi enne bolnitsa ei tule, kui ing akkab välja minema. (RKM II 447, 437 (59))

Siberi eestlaste ravimtaimede tundmine ja nende kasutamine oli kindlasti ulatuslikum, kui me ERA Siberi välitöödel seda valdkonda talletada suutsime, sest kõik kogujad ei tundnud piisavalt rahvabotaanikat. Enam on Siberi eestlaste ravimtaimede kasutamist uurinud Astrid Tuisk (vt nt Tuisk 2016, 45-64). Siberi looduses kasvavad taimed olid Eestimaa omadest märksa lopsakamad ja seetõttu ka raskesti äratuntavad. Ravimtaimede emakeelsete nimetuste asemel olid suuresti kasutusel venekeelsed, mitmeid külades kasutatavaid taimi ei suutnud me kindlaks teha. Metsas käimiseks jäi suviste välitööde jooksul vähe aega, talvel toimunud välitööd ei sobinud aga 
kuigivõrd rahvabotaanika-alase teabe kogumiseks. Ravimtaimi osati põhjalikult kirjeldada harva, küsitlejad ei osanud alati ka asjakohaseid täiendavaid küsimusi esitada. Kodudes leiduvate kuivatatud ravimtaimede kohta saime enamasti üldsõnalist teavet, nt:

Pune on närvide rahustamiseks, tsaiudeks ${ }^{24}$ korjavad. (RKM II 447, 296 (1) < naine, 59a)

Belogolounikud ${ }^{25}$ - neid hautati, kui pia kohiseb, joodi tsaiut. (RKM II 447, $454(10)<$ naine, 71a)

\section{Eesti Rahvaluule Arhiivi kogumismatkad aastatel 2012 ja 2013}

Paarkümmend aastat hiljem, 2012. ja 2013. aasta ERA Siberi välitöödel ${ }^{26}$ torkas silma, et piirkonna eesti külade elanikkond oli drastiliselt vähenenud - umbes poole võrra. Mõistagi olid pensioniealised naised ülekaalus, kuid näiteks Ülem-Suetuki külas oli üle kahekümne vallalise noormehe. Paraku noorikuid neile kohapeal ei jagunud, sest just tütarlapsed pidavat varmalt külast lahkuma. Hulk elumaju oli mahajäetud ja lagunemas. Ülem-Bulanka külas leidsime eest vaid üksikud eesti pered. Samas oli võrreldes 1990. aastatega elanike majanduslik olukord paranenud ja piirkonna eestlaste suhted emamaa sugulastega taas elavnenud.

Isiklik loomapidamine oli külas üks äraelamisviise. Oma tarbeks toidu kasvatamisel on Siberis pikaajaline traditsioon ja selle osakaal on siberlaste toidulaual tänapäeval märksa olulisem kui eestlastel Eestimaal. Siiski võis märgata, et võrreldes 1990. aastatega, kui kõik, kel vähegi tervist, püüdsid oma loomi pidada, olid paljud vanemad inimesed nüüd loomapidamisest loobunud. Nooremad lähevad kergemini kaasa moodsa ühiskonna survega, kus traditsiooniline toit on oma positsioone kaotamas. Ühtpidi ollakse avatud uuele ja moodsale, mida pakuvad poeketid, teisalt on hakatud teadvustama omakasvatatud toidu väärtust tervislikkuse seisukohalt (Korb 2015a, 147). Ülem-Suetuki ja Ülem-Bulanka vabapidamisel sigade kohta kuulsin sedakorda korduvalt, et külaelanike loomapidamine ${ }^{24}$ Teeks (vn).

${ }^{25}$ Angervaksad (vn).

${ }^{26}$ 2012. a välitöödel osalesid Anu Korb, Andreas Kalkun ja Eva Sepping; 2013. a välitöödel Anu Korb ja Villi Sulger. 
vastab tänapäevase maheliha-tootmise nõuetele. Kui paarkümmend aastat varem hindasid Siberi eestlased kõrge kalorsusega rasvarikkaid toite, siis järjest enam oli hakatud jälgima toidu kalorsust ja toiduainete kasulikkust organismile. Suuresti meedia mõjul oli kasvanud rahva üldine terviseteadlikkus: osa inimesi järgis hoolega tervisesaadetes ja kirjutistes antud tervisenõuandeid (Korb 2015a, 145). Siberi küladesse olid vahepeal jõudnud sügavkülmikud, seetõttu oli oluliselt vähenenud vajadus liha soolamise järele.

Ülem-Suetuki külas töötas velskri-ämmaemandana omaküla eestlane, keda inimesed usaldasid. Tervisekäitumist mõjutab paratamatult ka riiklik poliitika, näiteks lastetoetuste sidumine ema varajase rasedusaegse arvele võtmisega: pere kaotab lapse toetusrahad, kui ema end enne 12. nädalat kohalikus arstipunktis arvele ei võta. Kuna tulevased emad on velsker-ämmaemanda hoole all ja sünnitama minnakse haiglasse, kaob paratamatult ka osa lapse sünniga seotud kombestikust ja rahvameditsiinist.

ERA salvestusvõimalused olid 21. sajandil oluliselt paremad kui ERA Siberi välitööde algusaegadel, kuid Siberi küladest rahvameditsiini teadmiste kogumisvõimalused märgatavalt ahenenud.

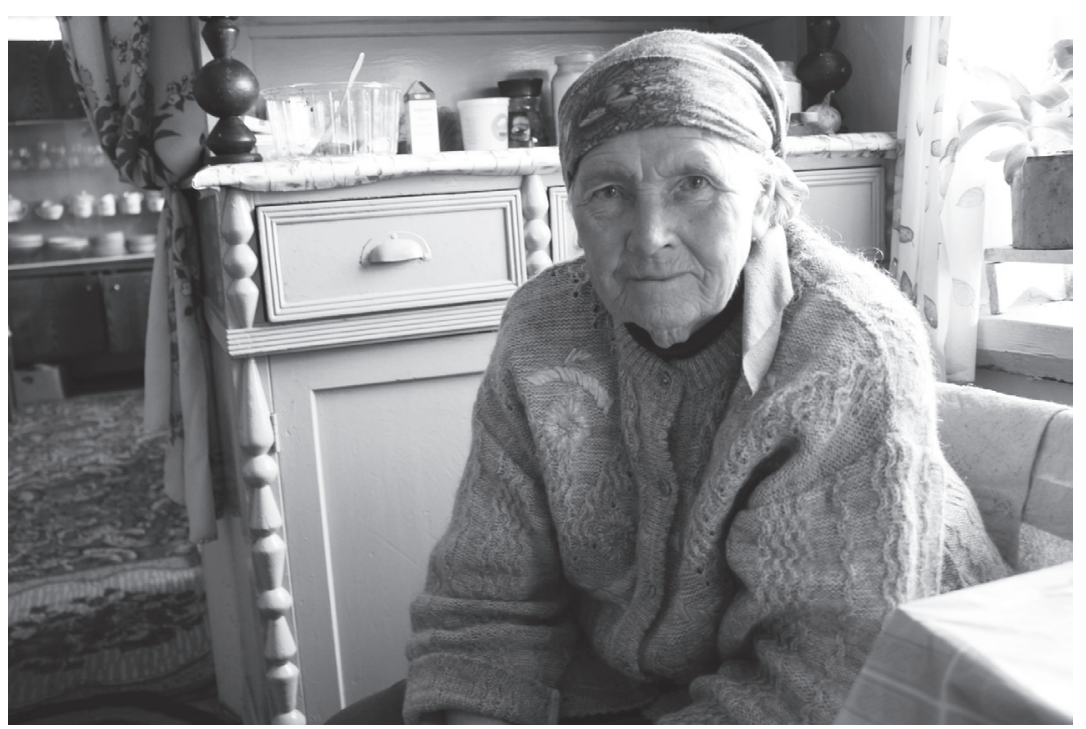

Ülem-Suetuki ravitseja Anna (Anni) Arel. Anu Korbi foto 2013 (ERA, VF 5387). 
Kuna paljud teadjad olid jõudnud teispoolsusse, noori, kes oleksid traditsiooni jätkamisest huvitatud, polnud piisavalt, olid ravitsemisoskused koondunud üksikute traditsiooni tundvate inimeste kätte. Need aga tunnetasid oma eristaatust ega jaganud teadmisi vabalt kõigile soovijaile nagu oli varem neis külades kombeks. Taevakirjas olevaid ravisõnu lubati siiski ümber kirjutada, sest endiselt peeti kinni vanast uskumusest, et taevakirja kopeerimist ei tohi keelata.

Mitmetes peredes leidus sarja "Eesti asundused" esimene raamat "Siin Siberi maa peal kasvanud" (1995, koostanud Anu Korb ja Kadri Peebo), mis hõlmab muu pärimuse hulgas ka 64 piirkonnast kogutud rahvameditsiini-teksti. Osa siberlasi kasutas raamatus leiduvaid ravisõnu ja rahvameditsiini tarkusi samuti kui kasutatakse pärandatud või kopeeritud käsikirjalisi ravisõnu, venekeelseid rahvameditsiini, maagia jm raamatuid, massimeedias kuuldud õpetusi jms. Mõni arvaski, et küladest kogutud tarkused on kord juba üles kirjutatud ja neid ei tarvitse enam koguda.

Ravimtaimede kasutamine oli viimastel aastatel külaelanike seas veidi kasvanud, sest Siberis kasvavaid taimi ja taimravi on hakatud enam väärtustama. Taimede kasutamise kohta hangiti teadmisi ka venekeelsest kirjandusest ja meedia vahendusel.

\section{Kokkuvõtteks}

Siberi eestlaste rahvapärase ravitsemisega seonduvat materjali pole kogunud rahvameditsiini uurimisele keskendunud teadlased, vaid seda on kogutud alates 1960. aastate lõpust osana frontaalsest kogumistööst. 1960.-1970. aastail Siberist kogutud rahvameditsiini-alane teave on arhiivi jõudnud tänu ühe inimese - Ottessoni järjekindlale tööle, kes kogukonna, kuhu ta ise kuulus, teadmisi väljaspoolsetele vahendas. Samas oli neil aastail talletatu suuresti mõjutatud valitsevast ideoloogiast ja kogumistöö juhendamisest, 1990. aastail ja hiljem on rahvameditsiiniga seonduvat saanud koguda piiranguteta.

Muutunud olid ka uurimisparadigmad. Kauge vahemaa ja suurte ekspeditsioonikulude tõttu oli Siberi eestlastelt otstarbekas koguda võimalikult mitmekesist materjali. Samas ei saa pärimuse frontaalse kogumise puhul eeldada, et üht osa sellest, rahvameditsiini puutuvat, suudetakse talletada ammendavalt. Mina ja mu välitööde kaaslased ei olnud spetsialiseerunud rahvameditsiini-uurimisele, 
kuid külades, kus traditsiooniline elukorraldus, külade perifeerne asend ja sõnamaagia hästi säilitanud naabrite lähedus olid aidanud püsida vanematel raviviisidel-võtetel ja raviloitsudel, oli seesugune pärimus vägagi esil ja tekitas minus tõelise uurija-huvi.

Mõistagi ei saa koguja eirata oma kultuurilist keskkonda, õpetust, valitsevat kogumistraditsiooni jm ning toimib sellele vastavalt, samas juhindub ta ka omaenese huvidest.

Vanemate raviviiside-võtete ja loitsude tundmine on Ida-Siberi eestlaste juures püsinud kauem kui Kodu-Eestis. Seda tingis nii praktiline vajadus kui ka sõnamaagia hästi säilitanud naabrite mõju. Siberis pole rahvaarstid aegade jooksul eriliselt silma paistnud, sest ravitsemisoskus on olnud vähemalt vanema põlve eestlaste arvates igaühele kättesaadav ja õpitav.

Nõukogude perioodil pikaaegse ühiskondlik-poliitilise surve tingimustes suutsid ravitsejad edasi tegutseda ja traditsioon püsis visalt. Ka 1990. aastate märksa vabamates tingimustes kuulus rahvapärane ravitsemine kogukonna üldteadmiste hulka. Kuna külakogukonnas aktsepteeriti eakamaid ravitsejaid, pärssis see nooremal põlvkonnal rahvameditsiini teadmiste omandamist. Uuele ja moodsale avatud noored ei pidanud ka loitsude ja ravitsemisoskuste omandamist alati vajalikuks. Traditsioonis saab püsida vaid see osa rahvameditsiinist, mida nooremad taaskasutavad ja edasi arendavad. Mitmete teadjate teispoolsusesse jõudmise ja külade elanike kiire vähenemise tõttu võis 21. sajandil täheldada Siberi eestlaste rahvapärase ravitsemisoskuse taandumist. Varasemad kogukonna üldteadmised olid koondunud üksikute teadjate kätte, kes tunnetasid oma erilisust ega jaganud oma oskusi enam vabalt kõigi kogukonna liikmetega. Samas oli suurenenud rahva terviseteadlikkus ja kasvanud meedia mõju selle suunamisel.

Artikli valmimist on toetanud Euroopa Liit Euroopa Regionaalarengu Fondi kaudu (Eesti-uuringute Tippkeskus); artikkel on seotud Haridus- ja Teadusministeeriumi uurimisprojektiga IUT 22-4. 


\section{Arhiivimaterjalid}

RKM - Riikliku Kirjandusmuuseumi (nüüd Eesti Kirjandusmuuseumi) käsikirjaline rahvaluulekogu kuni 1994.

\section{Kirjandus}

Assmann, Jan 2012. Kollektiivne mälu ja kultuuriline identiteet. - Akadeemia 10, 1775-1786.

Alver, Bente G. \& Selberg, Torunn 1989. Alternative Medicine in Today's Society. - Kvideland, Reimund \& Sehmsdorf, Henning, K. (toim). Nordic Folklore. Recent Studies. Indiana University Press, 207-220.

Erich, Oswald A. \& Beitl, Richard 1974. Wörterbuch der deutschen Volkskunde. Stuttgart: Alfred Grönen Verlag.

Halbwachs, Maurice 1985. Das kollektive Gedächtnis. Frankfurt am Main: Fischer Taschenbuch Verlag.

Hiiemäe, Mall 1989. Jakob Hurda rahvaluulekogumise printsiibid tänapäeval. - Eesti NSV Teaduste Akadeemia Toimetised. Ühiskonnateadused 38 (4), 310-315.

Hiiemäe, Reet 2002. Uued suunad rahvaluulekogumises alates 1980 . aastatest Eesti Rahvaluule Arhiivi laekunud ainese põhjal. Hiiemäe, Mall (koost). Kogumisest uurimiseni. Artikleid Eesti Rahvaluule Arhiivi 75. aastapäevaks. Eesti Rahvaluule Arhiivi Toimetused 20. Tartu: Eesti Kirjandusmuuseum, 280-293.

Kleinman, Arthur 1980. Patients and healers in the context of culture. An exploration of the borderland between anthropology, medicine and psychiatry. Comparative Studies of Health Systems and Medical Care. Berkeley: University of Californian Press.

Korb, Anu 2005. Venemaal rahvuskaaslasi küsitlemas. Folkloristliku välitöö metoodilisi aspekte. Studia Ethnologica et Folkloristica Tartuensia 9. Tartu: Tartu Ülikooli Kirjastus.

Korb, Anu 2006. Ravitsemisoskus kui pärimusrühma ühisteadmus: Siberi Rõžkovo küla näide. - Mäetagused 34, 87-110 (doi:10.7592/ MT2006.34.korb).

Korb, Anu (koost, toim) 2010. Siberi eestlaste elud ja lood. Eesti asundused V. Tartu: Eesti Kirjandusmuuseumi teaduskirjastus.

Korb, Anu 2013. Rahvaluule osakonna Siberi kaastöölise Rosalie Ottessoni ja teadurite-arhivaaride dialoog aastatel 1969-1976. - Mäetagused 54, 7-26 (doi:10.7592/MT2013.54.korb).

Korb, Anu 2015a. Oma toit: muutustest Siberi eestlaste toidukultuuris. Mäetagused 59, 125-150 (doi:10.7592/MT2015.59.korb).

Korb, Anu (koost, toim) 2015b. Roosi Siberi lood. Eesti asundused VII. Tartu: Eesti Kirjandusmuuseumi teaduskirjastus. 
Kõiva, Mare 1990. Veel kord rahvaluulest ("Eesti folkloristika täna ja homme"). - Keel ja Kirjandus 8, 451-455.

Kõiva, Mare 1992. Loitsud ja rahvaarstid. - Rüütel, Ingrid (toim). IdaVirumaa rahvakultuurist. Tallinn: AS Infotrükk, 117-131.

Kõiva, Mare 1995. Loitsust riituseni. - Hiiemäe, Mall \& Kõiva, Mare (toim). Rahvausund tänapäeval. Tartu: Eesti Keele Instituut, 175-194.

Kõiva, Mare 1997. The Transmission of Knowledge among Estonian Witch Doctors. - Rüütel, Ingrid \& Kuutma, Kristin (toim). The Family as the Tradition Carrier. Conference Proceedings. Vol. 2. NIF Publications 31. Tallinn: Nordic Institute of Folklore, 75-95.

Kõiva, Mare 1998. Palindroomidest, aga ennekõike tähtvormelitest. - Kalda, Mare \& Kõiva, Mare. Sator I. Artikleid usundi-ja kombeloost. Tartu: Eesti Keele Instituut, rahvausundi töörühm, 190-213 (http://www. folklore.ee/rl/pubte/ee/sator/sator1/sator1-11.pdf - 18.02.2018).

Kõiva, Mare 1999. Numeraalid. Ühest loitsude alaliigist. - Eesti Rahva Muuseumi aastaraamat XLIII. Tartu: Eesti Rahva Muuseum, 115-132.

Kõivupuu, Marju 2000. Rahvaarstid Võrumaalt. Noor ja vana Suri Hargla kihelkonnast. Võru: Võro Instituut.

Kõresaar, Ene 2005. Elu ideoloogiad. Kollektiivne mälu ja autobiograafiline minevikutõlgendus eestlaste elulugudes. Eesti Rahva Muuseumi sari 6. Tartu: Eesti Rahva Muuseum.

Loorits, Oskar 1940. Meie sisetööst ja välisabist. - Rahvapärimuste Selgitaja II (9), 145-147.

Must, Aadu 2012. Siber ja Eesti. Jalaraua kõlin. Tartu: Tartu Ülikooli Kirjastus.

Nigol, August 1918. Eesti asundused ja asupaigad Venemaal. Tartu.

Rooks, G. 1929. Ebaarstimine Eestis. - Eesti Arst 10, 377-382.

Rorbye, Birgitte 2003. Rahvameditsiinist meditsiinifolkloristikani. - Mäetagused 22, 7-19 (doi: 10.7592/MT2002.22.birg).

Suojanen, Päivikki 1999. Folkloren Tutkimuksen metodiikkaa. Opetusmoniste. Villa Rana 2. Jyväskylä: Jyväskylän yliopisto.

Tamm, Marek 2013. Ajalugu, mälu ja mäluajalugu: uutest suundadest kollektiivse mälu uuringutes. - Ajalooline Ajakiri 1 (143), 111-134 (doi: 10.12697/AA.2013.1.05).

Templing = Темплинг, Владимир Яковлевич 2005. Сельские врачеватели в сибирском социуме. - Карабулатова, Ирина С. (ред). Живая традиция заговора Сибири: сакрально-ритуальный дискурс знахарской практики. Тюмень, 213-299.

Tuisk, Astrid 2016. Siberi ravimtaimed eesti kogukondade kasutuses. Vahtramäe, Ell (toim). Eesti Põllumajandusmuuseumi aastaraamat V. Tartu: Eesti Põllumajandusmuuseum, 45-64.

Tupits, Ave 2009. Käsitlusi rahvameditsiinist: mõiste kujunemine, kogumisja uurimistöö kulg Eestis 20. sajandil. Dissertationes Folkloristicae Universitatis Tartuensis 13. Tartu: Tartu Ülikooli Kirjastus. 
Vallikivi, Laur 2005. Arktika nomaadid šamanismi ja kristluse vahel. Jamb-to neenetsite pöördumine baptismi. Studia Ethnologica et Folkloristica Tartuensia 8. Tartu: Tartu Ülikooli Kirjastus.

WHO 2005 = National Policy and Traditional Medicine and Regulation of Herbal Medicines. Report of a WHO Global Survey. Report of a WHO Global Survey. Geneva: World Health Organisation (http://apps.who. int/medicinedocs/en/d/Js7916e/ - 18.02.2018).

\section{Summary}

\section{Healers, explanations of diseases and treatment methods of Estonians in the Minusinsk area in Eastern Siberia. Changes in tradition and collection context}

Keywords: collection of folklore, community, Estonians in Siberia, folk medicine, healers, ideology

The article covers the knowledge on folk medicine of Estonians born and raised in the villages of Upper-Suetuk (Верхний Суэтук) and Upper-Bulanka (Верхняя Буланка) in the Minusinsk area in Eastern Siberia, collected from 1969 to 2013: written records as well as audio and video recordings starting from the 1990s. Because the two villages lie close to each other and have similar lore, the collected material can be considered the lore of Estonians in the Minusinsk area.

Ancestors of the Estonians in that area emigrated during the last decade of the 19th century and early 20th century in a bid to find a private plot of land or ended up in the area even earlier as deportees and exiles sent by the government of the Russian Empire.

In addition to other lore, material on healers, explanations on diseases, treatment methods, etc. has been collected from Estonians in Siberia for the Estonian Folklore Archives from the end of the 1960s. The information collected on folk medicine in Siberia from 1960 to 1970 has ended up in the archive thanks to the systemic work of one person - Rosalie Ottesson, who helped share the knowledge of the community that she was also a part of. The material dating from that period is largely influenced by the ruling ideology and the instructions given for carrying out the collection process. The collection of material on folk medicine was subject to far fewer constrictions from the 1990s onwards, but there was also a change in the research paradigm. Thereafter, information on folk medicine traditions among Estonians in Siberia was collected during the fieldwork of the Estonian Folklore Archives. 
Naturally, the collector cannot ignore their own cultural environment, teachings, the dominant collection tradition, etc. and acts accordingly while also proceeding from their personal interests.

Because of the distance and costliness of the expeditions, it made sense to collect as diverse material as possible from Estonians in Siberia. At the same time, it would be wrong to expect to get a comprehensive record of a particular branch of lore (folk medicine) when collecting various lore.

Knowledge of old treatment ways and methods has survived longer among Estonians in Eastern Siberia than in Estonia locally. This was caused by practical need as well as the influence of neighbouring groups were verbal charms have been well preserved. Healers have not stood out in particular in Siberia during different periods because healing skills have been accessible and learnable by all, at least in the opinion of the older generation of Estonians. Healers were able to continue their practice under the long-term societal and political pressures of the Soviet period. The tradition persisted. Folk medicine was part of the general knowledge of the community even in the 1990s when the situation was far less constrictive.

According to the theory of collective memory, membership of a particular society and its culture depends on socialisation and traditions, whereas the only things remaining form the past are those that society can reconstruct in its contemporary background system. The fact that older healers were deemed eligible in the village community restricted the acquisition of folk medicine knowledge among the younger generation. Young people who were open to novel and modern healing methods did not always find it necessary to learn charms and healing skills. The death of a number of wise men/women and the rapid decrease of people living in the village in the 21st century caused folk medicine skills to regress among Estonians in Siberia. Knowledge that was once shared in the community in general now converged to a limited number of wise men/women who were aware of their special status and no longer shared their skills freely with all members of society. At the same time, people also became more aware of their health, and the media grew more influential in guiding that awareness. 


\section{PILDI SISSE MINEK. Artikleid välitööde alalt}

\section{Koostanud ja toimetanud EDA KALMRE}

http://www.folklore.ee/rl/pubte/ee/cf/pildisisse

ISBN 978-9949-586-93-6

DOI $10.7592 / \mathrm{TF} 11$

Tartu 2019

Trükis ilmunud:

Pildi sisse minek. Artikleid välitööde alalt.

Tänapäeva folkloorist 11. Tartu 2019

Sarja peatoimetaja: Eda Kalmre

Kogumiku koostaja ja toimetaja: Eda Kalmre

Keeletoimetaja: Asta Niinemets

Kaanekujundus: Artur Kuus

Küljendus: Diana Kahre

Veebiväljaanne: Diana Kahre

Trükitud Eesti Kultuurkapitali toetusel. Väljaande valmimine on seotud Euroopa Liidu Euroopa Regionaalarengu Fondi (Eesti-uuringute Tippkeskus) ja Eesti Haridus- ja Teadusministeeriumi uurimisprojektiga IUT 22-5. Väljaande valmimist on toetanud Akadeemiline Rahvaluule Selts.

E-raamatu valmimist toetas: EKKM14-344 Eesti keele, kultuuri ja folkloori kasutusalade laiendamine ja tutvustamine elektroonilistel infokandjatel.

(C) Eesti Kirjandusmuuseum 2019

(C) Eda Kalmre ja autorid

(C) Artur Kuus 